\title{
Iron Bacterial Phylogeny and their Execution Towards Iron Availability in Equatorial Indian Ocean and Coastal Arabian Sea
}

\author{
RAJU RAJASABAPATHY, CHELLANDI MOHANDASS*, AJAKKALAMOOLE SRINIVAS VIJAYARAJ, \\ VARSHA VINAYAK MADIVAL and RAM MURTI MEENA
}

Biological Oceanography Division, CSIR-National Institute of Oceanography, Dona Paula, INDIA

Submitted 31 January 2013, revised 24 June 2013, accepted 18 october 2013

\begin{abstract}
Based on distinct colony morphology, color, size, shape and certain other traits, 92 bacterial isolates were investigated to understand their managerial ability on iron from the Arabian Sea and Equatorial Indian Ocean samples. The ARDRA (amplified rDNA restriction analysis) applied to eliminate the duplication of the bacterial strains, resulted 39 different banding patterns. The $16 S$ rRNA gene sequencing data indicate the dominancy of three phylogenetic groups, $\alpha$-Proteobacteria (10.25\%), $\gamma$-Proteobacteria (35.89\%) and Bacilli (53.84\%) in these waters. Marinobacter and Bacillus were the only common genera from both of the regions. Pseudoalteromonas, Halomonas, Rheinheimera, Staphylococcus and Idiomarina were some of the other genera obtained from the Arabian Sea. Erythrobacter, Roseovarius, Sagittula and Nitratireductor were found mostly in Equatorial Indian Ocean. In addition, 16S rRNA gene sequence data of some of our iron bacterial strains belong to novel species and one isolate ASS2A could form a new genus. Close to $23 \%$ of the isolates were able to produce high affinity sets of ligands like siderophores to mediate iron transport into the cell. The current study indicated that the Equatorial Indian Ocean species were well adapted to oxidize iron as an electron acceptor and the Arabian Sea species preferably go through siderophore production.
\end{abstract}

Ke y w ord s: Iron bacteria, 16S rRNA gene, Equatorial Indian Ocean, Arabian Sea, Siderophores

\section{Introduction}

Iron $(\mathrm{Fe})$ is the fourth most abundant element in the Earth's crust, and the second most abundant element that is redox-active in near-surface aqueous habitats, providing it the most vital metal in the environment (Cornell and Schwertmann, 1996; Edwards et al., 2004). The largest source of iron in the oceans is probably the atmosphere and this comes mainly from the wind erosion of soils to form dust. Iron is involved in many key biological processes like photosynthesis, $\mathrm{N}_{2}$ fixation, methanogenesis, $\mathrm{H}_{2}$ production and respiration, oxygen transport, gene regulation and DNA biosynthesis (Andrews et al., 2003). Microorganisms are involved in the precipitation and solubilization of iron by growing them at the expense of energy gained from the oxidation of reduced iron or by reduction of ferric ions (Cameron et al., 1984). Iron-oxidizing bacteria (FeOB) have been noticed in a wide range of environments and exposed to increase the rate of Fe oxidation by up to four orders of magnitude compared with the rate of strictly abiotic oxidation (Sogaard et al., 2001). FeOB are important catalysts of Fe cycling; on the other hand little is known about their diversity and distribution in various environments (Wang et al., 2009). Secretion of siderophores, the iron solubilizing material produced by the marine bacteria to facilitate the iron uptake into microbial cells has been reported by Trick (1989) and Okujo et al. (1994). Marine bacteria hold more iron per biomass than phytoplankton, the major primary producers (Tortell et al., 1996). For instance the bacterium Thiobacillus ferrooxidans gains energy from ferrous ion oxidation, but a wide variety of bacteria may deposit ferric iron without necessarily obtaining energy from the process.

Most of the iron in the seawater is present in the oxidation state $\mathrm{Fe}(\mathrm{III})$ which in alkaline conditions of sea should readily form insoluble iron oxides (Turner and Hunter, 2001). Although heterotrophic bacteria require up to one micro molar iron for growth, the total amount of iron in surface ocean water is sub nano molar. Dissolved iron level in open ocean water is about $20 \mathrm{pmol}$ $-1 \mathrm{nmol} / \mathrm{l}$ (Wu and Luther, 1994), which is much lower than the concentration required for most of the microorganisms for their growth. This limiting amount of iron has implications in the biogeochemical cycling of

\footnotetext{
* Corresponding author: C. Mohandass, Biological Oceanography Division, CSIR-National Institute of Oceanography, Dona Paula, Goa-403 004, India; phone: +91(0)-832-2450414; fax: +91(0)-832-2450606; e-mail: cmohan@nio.org
} 
carbon and in limiting phytoplankton growth. Marine bacteria can successfully compete for this limited nutrient using a specialized iron transport system, including the production and release of siderophores. Chemically siderophores are low molecular weight metabolites with masses of $<2000 \mathrm{Da}$ that have high affinity for ferric ion (Schalk et al., 2011). The role of these compounds is to scavenge iron from the environment and to make the mineral which is almost always essential, available to the microbial cell (Reid and Butler 1991; D'Onofrio et al., 2010). In this study we planned to investigate the culturable fraction of iron bacterial diversity from the Arabian Sea (AS) and Equatorial Indian Ocean (EIO) which are of having moderate and low iron concentrations to compare and to understand how these two different environments fulfill the iron requisite of the bacteria present over.

\section{Experimental}

\section{Materials and Methods}

Sampling details. EIO Sampling was carried out during the cruise track of Boris Petrov ABP\#37 from June 09 to July 10, 2009; stations were occupied at one degree intervals across the equator along $83^{\circ} \mathrm{E}$ from $1^{\circ} \mathrm{N}$ to $5^{\circ} \mathrm{S}$. Fifty five sediment samples and 98 water samples were collected and analyzed. AS water and sediment samples were collected at different locations of Off Goa during the cruise by coastal research vessel Sagar Sukti (SASU\#185, August 2009) along $15^{\circ} \mathrm{N}$ between 72 and $73^{\circ} \mathrm{E}$.

Isolation of iron bacteria. Iron Bacteria were isolated using the media M622- HiMedia, Mumbai (g/l: Glucose 0.15, Ammonium sulphate 0.5, Calcium nitrate 0.01 , Dipotassium phosphate 0.05 , Magnesium sulphate 0.05, Potassium chloride 0.05, Calcium carbonate 0.1, Vitamin B12 0.00001, Thiamine 0.0004, Agar 10.0). Appropriately diluted samples were spread plated on Iron bacterial isolation medium prepared in half strength seawater and incubated for 3-5 days at $30^{\circ} \mathrm{C}$. Bacterial colonies appeared on the media plates were isolated and purified for further analyses.

Genomic DNA extraction and PCR amplification of 16S rRNA gene. The genomic DNA was extracted from all the isolates using DNeasy kit (69506, Qiagen) according to the manufacturer's protocol and 16S rRNA genes of the bacterial isolates were amplified using $27 \mathrm{~F}$ (5'-AGA GTT TGA TCC TGG CTC AG-3') and 1492R (5'-GGT TAC CTT GTT ACG ACT T-3') universal forward and reverse $16 \mathrm{~S}$ rDNA primers (Lane, 1991). The PCR reaction mixture contained $1 \times$ PCR buffer, 1.5 $\mathrm{mM} \mathrm{MgCl}, 200 \mu \mathrm{M}$ of each dNTP's, $1 \mathrm{U}$ of Taq DNA polymerase (Genei, Bangalore), 10 pmol of each forward and reverse oligonucleotide primers and approxi- mately 25-50 ng of genomic DNA. The amplification profile consisted of an initial denaturation at $94^{\circ} \mathrm{C}$ for $3 \mathrm{~min}$, followed by 35 cycles at $94^{\circ} \mathrm{C}$ for $1 \mathrm{~min}, 55^{\circ} \mathrm{C}$ for $1 \mathrm{~min}$ and $72^{\circ} \mathrm{C}$ for $1 \mathrm{~min}$. This was followed by a final extension step of $72^{\circ} \mathrm{C}$ for $5 \mathrm{~min}$. The samples were held at $4^{\circ} \mathrm{C}$ until further analyses were done.

Amplified rDNA restriction analysis (ARDRA). The ARDRA technique was carried out to identify the variations in the banding patterns among the bacterial groups. 16S rRNA gene was digested using the four base-cutting restriction enzyme Alu I with appropriate buffers (Fermentas) according to the manufacturer's protocol. The $20 \mu \mathrm{l}$ of the above reaction mixture was incubated at $37^{\circ} \mathrm{C}$ for $3 \mathrm{~h}$. Restriction fragments were separated using 2.5\% TAE-agarose gel at $60 \mathrm{~V}$ for $2 \mathrm{~h}$ and viewed on Alphaimager-2200 gel documentation system (Alpha Innotech, USA).

16S rRNA gene sequencing and phylogenetic analysis. DNA sequencing for these samples were performed in $3130 \mathrm{xl}$ genetic analyzer (Applied Biosystems, USA) at National Institute of Oceanography. Nucleotide sequences thus obtained were assembled using DNABaser V.3 software. The PINTAIL program (Ashelford et al., 2005) was used to check chimera formations in our sequences. The nucleotide sequences of the isolates obtained were compared with the sequences available in GenBank database using BLAST software (www.ncbi. nlm.nih.gov) and 16S rDNA sequence similarity of $\geq 97 \%$ were considered as a phylotype. Further sequence alignment and comparison was performed using multiple sequence alignment program Clustal X 1.81 (Thompson etal., 1997). Neighbor-joining method was employed to construct the Phylogenetic tree using MEGA4 software (Tamura et al., 2007) and the maximum likelihood method was adopted for calculating the evolutionary distance (Tamura et al., 2004). The topology of the phylogenetic tree was evaluated by bootstrap analysis with 1,000 replications. The sequences were submitted to NCBI-GenBank and accession numbers were assigned from JQ905060 to JQ905098.

Screening of siderophore producing bacteria. To screen the low molecular-weight Fe(III) specific ligands (siderophores), Chrome azurol sulphonate (CAS) plate method was used (Schwyn and Neilands, 1987) and the media contains (g/L) CAS - 0.726; Hexadecyltrimethylammonium bromide (HDTMA) - 0.1456; Iron solution ( $\left.1 \mathrm{mM} \mathrm{FeCl}_{3}, 10 \mathrm{mM} \mathrm{HCl}\right)-2 \mathrm{~mL}$; Peptone - 5.0; Yeast extract - 1.0 and Agar - 20.0 prepared in $50 \%$ seawater. The bacterial cultures were spot inoculated in the medium and incubated for 24-72 h. Appearance of orange/yellow zone around the colony indicated siderophore production.

Characterization of siderophores. Cell free culture supernatants were examined for various types of siderophores i.e., hydroxamate nature by $\mathrm{FeCl}_{3}$ and tetrazo- 
lium tests (Neilands, 1981; Snow, 1954), catecholates by Arnow's test (Arnow, 1937) and carboxylate siderophores by spectrophotometric test (Shenker et al., 1992).

Quantification of siderophores. Quantitative estimation of siderophores was done by CAS-shuttle assay (Payne, 1994). In which $0.5 \mathrm{~mL}$ of culture supernatant was mixed with $0.5 \mathrm{ml}$ of CAS reagent, and absorbance was measured at $630 \mathrm{~nm}$ against a reference consisting of $0.5 \mathrm{ml}$ of uninoculated broth and $0.5 \mathrm{ml}$ of CAS reagent. Siderophore content in the aliquot were calculated by using the formula: \% siderophore units $=(\mathrm{Ar}-\mathrm{As}) / \mathrm{Ar}$ (Where, Ar = absorbance of reference at $630 \mathrm{~nm}$ (CAS reagent) and As = absorbance of sample at $630 \mathrm{~nm}$ )

UV-Visible spectrophotometer scanning. Bacterial cultures were grown in TYES medium (g/l: Tryptone 4.0, Yeast Extract $0.04, \mathrm{CaCl}_{2} .2 \mathrm{H}_{2} \mathrm{O} 0.2, \mathrm{MgSO}_{4} .7 \mathrm{H}_{2} \mathrm{O} 0.5$, Glucose 0.05 ) for 6 days at $30^{\circ} \mathrm{C}$. The cells were removed by centrifugation at $6000 \times \mathrm{g}$ for $15 \mathrm{~min}$. The $\mathrm{pH}$ of the supernatant were adjusted to 2.0 with $12 \mathrm{~N} \mathrm{HCl}$ and extracted with 0.4 volume of ethyl acetate using separating funnel. The extracts were then concentrated by using rotary vacuum evaporator (Roteva, Equitron). Dried sample was re-suspended with $1 \mathrm{ml}$ of methanol and subjected to scan from 200-800 nm under UVVisible spectrophotometer (UV-2450, Shimadzu). Base line was corrected with the solvent methanol.

\section{Results and Discussions}

A total of 92 bacterial colonies were isolated from the iron media based on morphological characteristics like colour, size, shape, texture, Gram's and spore staining. Most of the colonies were circular, white or dull white and only few were accounted for yellow. Around 95\% of the isolates were rod shaped and very few were in coccid nature (Fig. 1). Seventy percent of the EIO isolates were gram positive, spore producers and in contrast $92 \%$ of the AS isolates were gram negative (data not shown).

Approximately 1500 nucleotides long PCR amplified $16 \mathrm{~S}$ rDNA of the bacterial isolates were differentiated for its phylotypes using ARDRA analysis with Alu-I endonuclease (AG $\downarrow$ CT). ARDRA of the culturable iron bacterial isolates sorted them into various phylotypes (39 restriction patterns) which were then sequenced. Identifications based on 16S rRNA gene sequence comparison to BLAST analysis of the iron bacteria are shown in Table I. Chimera check indicated that there were no anomalies detected from the sequences. The $16 \mathrm{~S}$ rRNA gene sequences expressed three different bacterial classes, each one represented by different families: Bacilli (Bacillaceae and Staphylococcaceae), a-Proteobacteria (Rhodobacteraceae, Erythrobacteraceae and Phyllobacteriaceae) and $\gamma$-Proteobacteria (Pseudoalteromonadaceae, Alteromonadaceae, Alcanivoracaceae, Pseudomonadaceae, Idiomarinaceae,

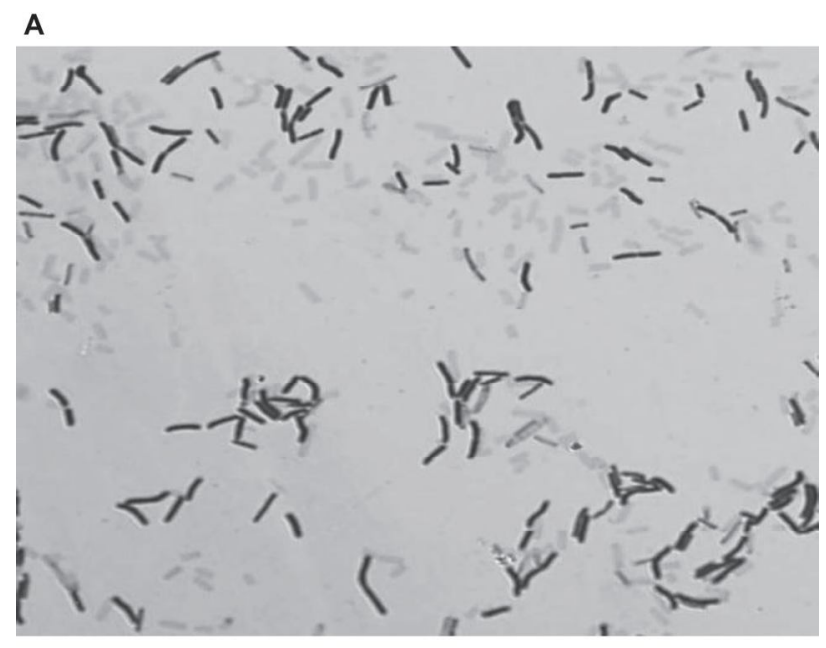

B

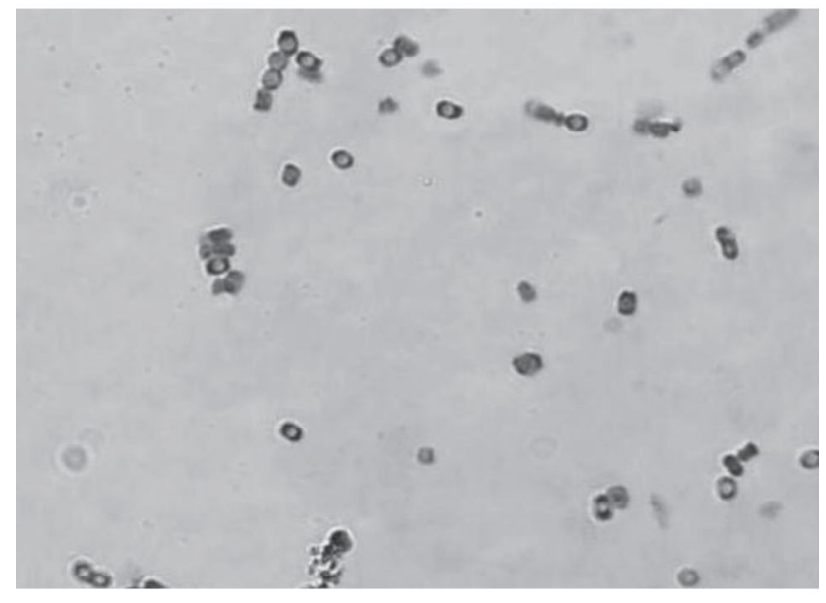

C

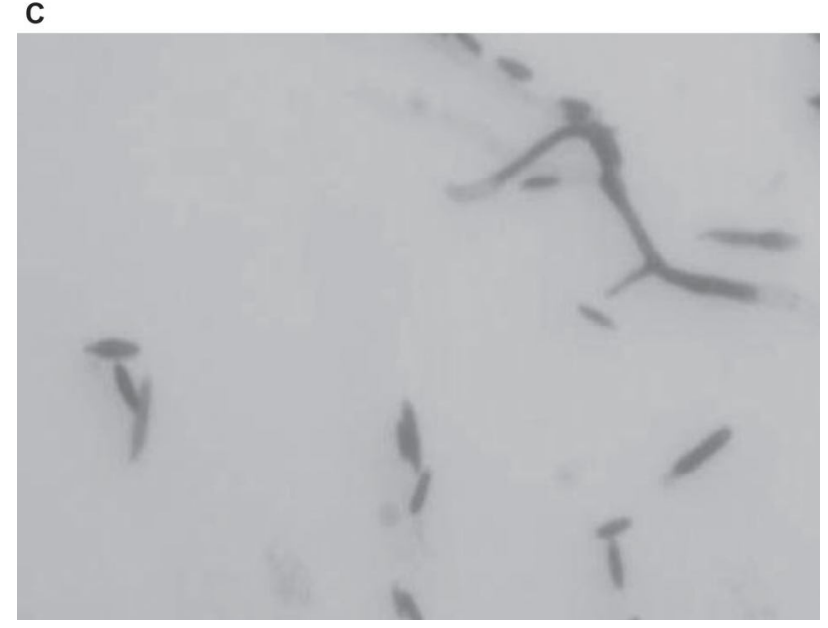

Fig. 1. Morphology of few representative bacteria (A: OS1B, B: ASW2C, C: NOS6).

Chromatiaceae and Halomonadaceae). 16S rRNA gene sequencing analysis exhibited 13 different genera belong to Halomonas, Rheinheimera, Staphylococcus, Marinobacter, Idiomarina, Alcanivorax, Erythrobacter, Roseovarius, Sagittula, Nitratireductor, Pseudoalteromonas, Pseudomonas and Bacillus (Table I).

Iron bacterial 16S rRNA gene similarity levels were mostly $\geq 97 \%$ when compared with the published 
A

55 OSIB

$85-$ OS 22

57 Bacillus nealsonii (EU656111)

100

$98 \quad \begin{aligned} & \text { OW18 } \\ & -O S 36 B \\ & \text { OS42 }\end{aligned}$

- Bacillus infantis (AY904032)

[ Bacillus oceanisediminis (GQ292772)

90 [ Bacillus firmus (X60616)

$6 0 \longdiv { \text { OSS4A } }$

- OS43

OW3

Bacillus megaterium (D16273)

Bacillus aryabhattai (EF114313)

98 OS46R

Bacillus flexus IFO (AB021185)

- NOS48

[ Bacillus soli (AJ542513)

98 Bacillus drentesis (AJ542506)

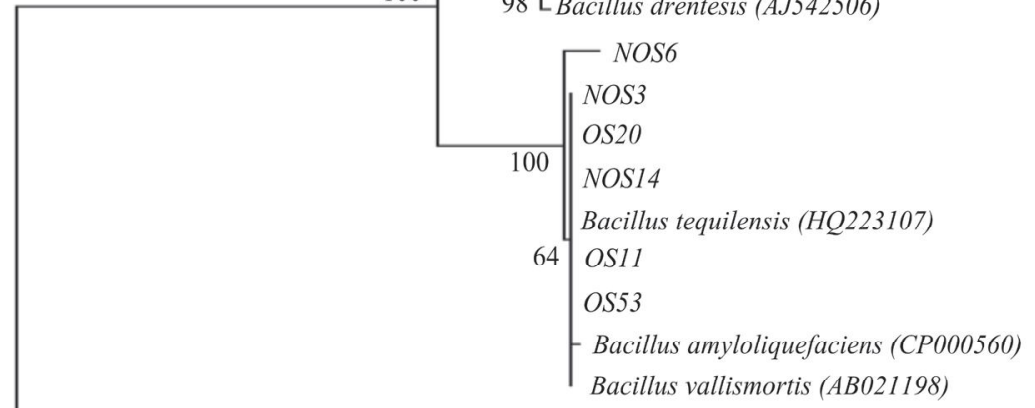

Bacillus vallismortis (AB021198)

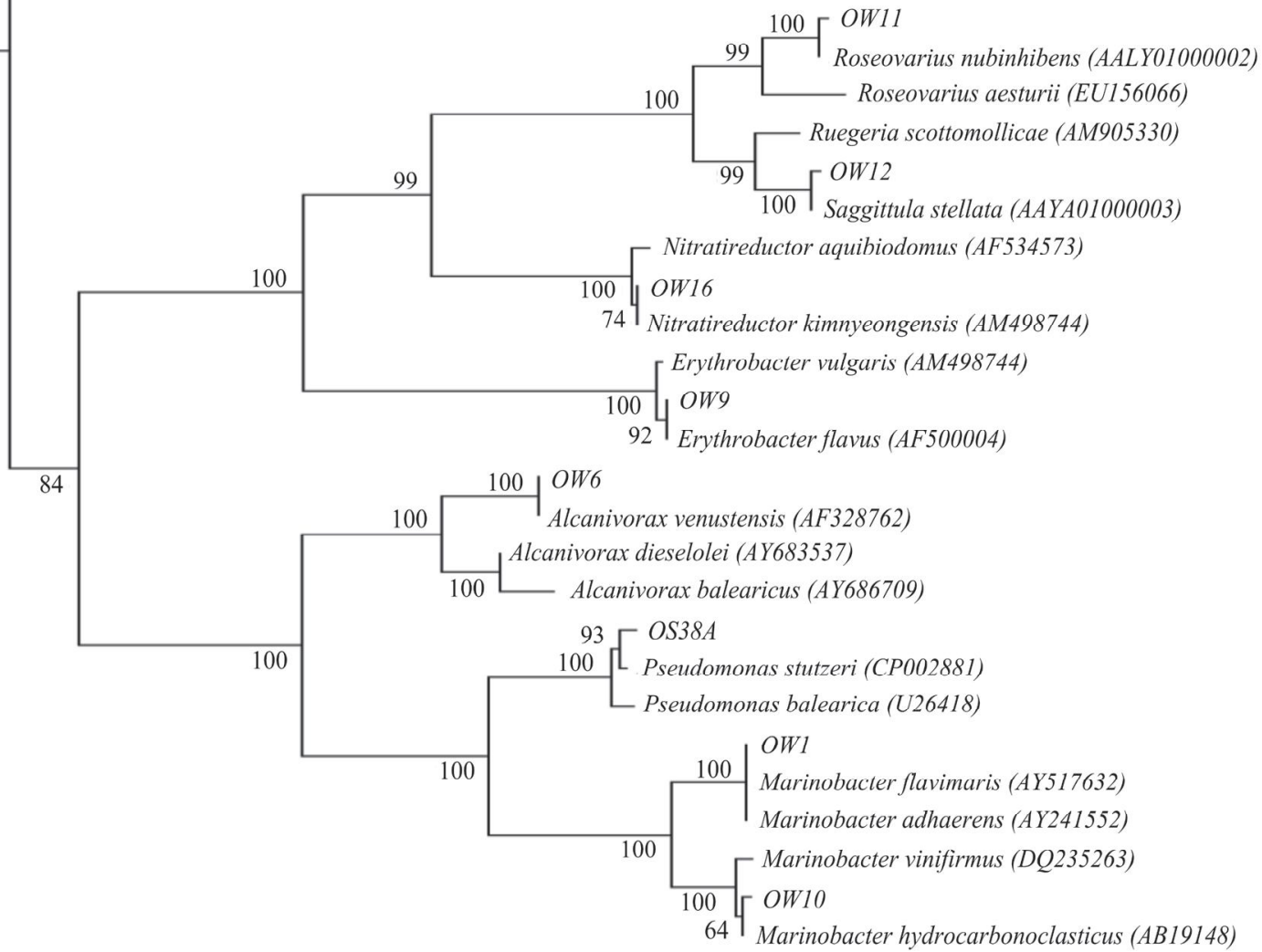




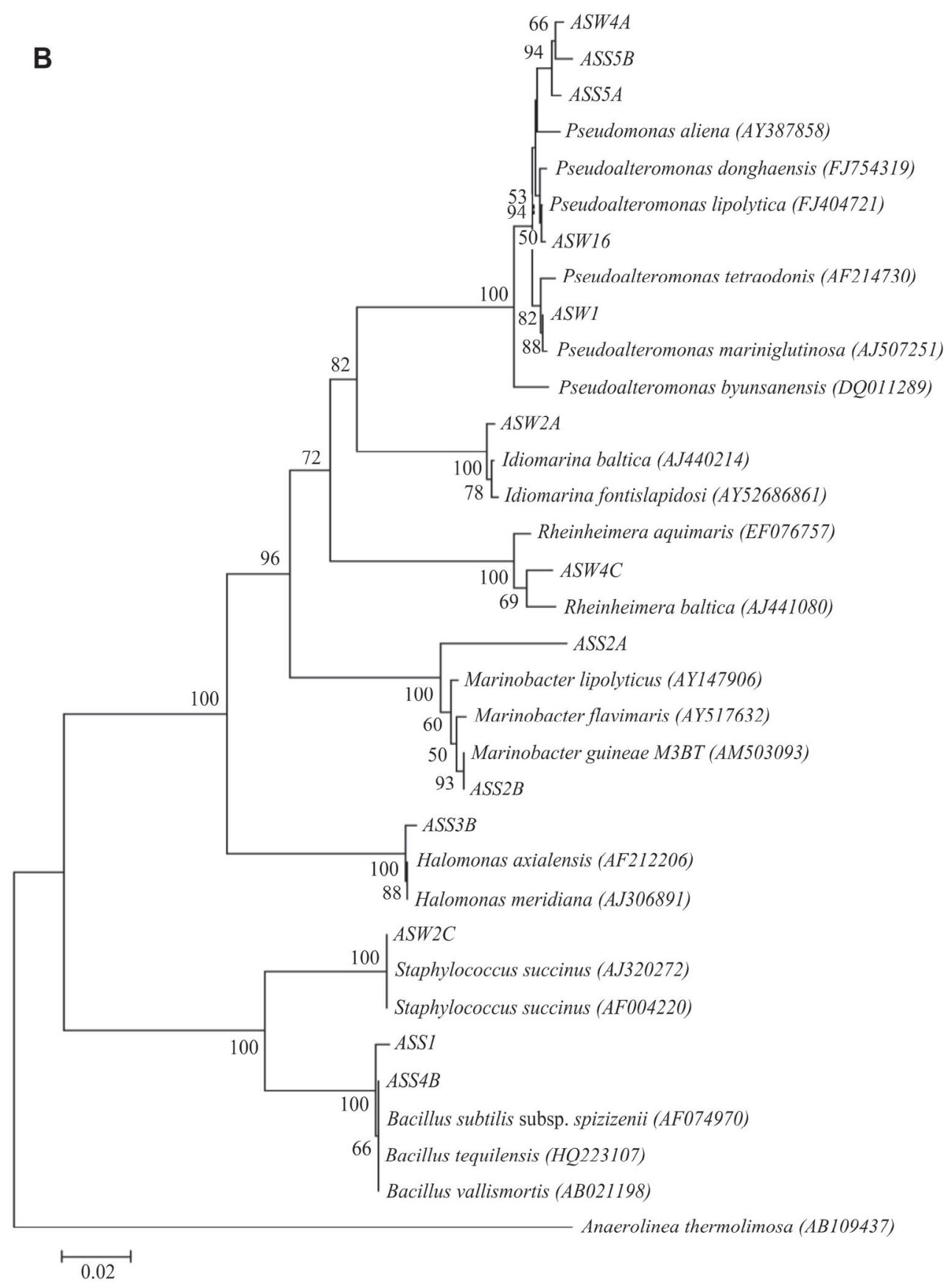

Fig. 2. The Neighbor-Joining tree constructed based on evolutionary distances and computed using the Maximum Composite Likelihood method representing relationship between the 16S rRNA sequence of iron bacteria (a. Equatorial Indian Ocean; b. Arabian Sea). Bootstrap values (expressed as percentages of 1000 replications) greater than $50 \%$ are shown at the tree branch points. Anaerolinea thermolimosa is used as an out group. Bacteria with accession numbers provided in the phylogenetic tree were retrieved from GenBank database to know the relationship of our bacteria.

GenBank database. But some of the Arabian Sea isolates like ASW4a and ASS5a were matched only $96.8 \%$ with the existing database. Since the similarity indexes are showing lower than $97 \%$, this could expect to form a new species under the genera Pseudoalteromonas. Further one of the isolate ASS2A from the Arabian Sea observed the similarity level of $94.7 \%$ may form a potential new genus in the family Pseudoalteromonadaceae. Additional experiments like Fatty Acid Methyl Ester analysis and DNA-DNA relatedness have to be done to confirm this. Even though more than $97 \%$ similarity level were observed for some of the Indian Ocean isolates like OW6, OW10, OW11, OW12, OW18, OS1B, OS1C and OS42, these species were reported very rarely in the literatures. Above results clearly indicate many novel and rare bacterial species on Iron bacteria to be included in the diversity data bases.

Much less information is available about iron oxidizing bacteria from the marine environment because their habitats appear limited primarily to deep sea 
Table I

$16 \mathrm{~S}$ rRNA gene identity of iron bacteria from EIO and AS.

\begin{tabular}{|c|c|c|c|c|c|}
\hline Sr. No & Strain no. & Bacteria identified by $16 \mathrm{~S}$ rRNA gene & Phyla/Class & Accession no. & Similarity \% \\
\hline 1 & OW1 & Marinobacter flavimaris & $\gamma$-Proteobacteria & JQ905060 & 99.6 \\
\hline 2 & OW3 & Bacillus flexus & Bacilli & JQ905061 & 99.2 \\
\hline 3 & OW6 & Alcanivorax venustensis & $\gamma$-Proteobacteria & JQ905062 & 100 \\
\hline 4 & OW9 & Erythrobacter flavus & a-proteobacteria & JQ905063 & 99.9 \\
\hline 5 & OW $10^{*}$ & Marinobacter hydrocarbonoclasticus & $\gamma$-Proteobacteria & JQ905064 & 97.7 \\
\hline 6 & OW11 & Roseovarius nubinhibens & $\alpha$-Proteobacteria & JQ905065 & 99.8 \\
\hline 7 & OW12 & Sagittula stellata & a-Proteobacteria & JQ905066 & 98.2 \\
\hline 8 & OW16* & Nitratireductor kimnyeongensis & a-Proteobacteria & JQ905067 & 100 \\
\hline 9 & OW18 & Bacillus aryabhattai & Bacilli & JQ905068 & 98.9 \\
\hline 10 & OS1B & Bacillus nealsonii & Bacilli & JQ905069 & 98.3 \\
\hline 11 & OS1C & Bacillus oceanisediminis & Bacilli & JQ905070 & 98.6 \\
\hline 12 & OS11 & Bacillus tequilensis & Bacilli & JQ905071 & 97.8 \\
\hline 13 & OS12 & Bacillus circulans & Bacilli & JQ905072 & 99.7 \\
\hline 14 & OS20 & Bacillus tequilensis & Bacilli & JQ905073 & 100 \\
\hline 15 & OS22 & Bacillus nealsonii & Bacilli & JQ905074 & 98.7 \\
\hline 16 & OS36B & Bacillus aryabhattai & Bacilli & JQ905075 & 99.3 \\
\hline 17 & OS $38 A^{*}$ & Pseudomonas stutzeri & $\gamma$-Proteobacteria & JQ905076 & 98.2 \\
\hline 18 & OS42 & Bacillus megaterium & Bacilli & JQ905077 & 97.7 \\
\hline 19 & OS43 & Bacillus nealsonii & Bacilli & JQ905078 & 97.6 \\
\hline 20 & OS46R & Bacillus flexus & Bacilli & JQ905079 & 99.0 \\
\hline 21 & OS53 & Bacillus vallismortis & Bacilli & JQ905080 & 100 \\
\hline 22 & OSS4A & Bacillus oceanisediminis & Bacilli & JQ905081 & 99.6 \\
\hline 23 & NOS3 & Bacillus vallismortis & Bacilli & JQ905082 & 100 \\
\hline 24 & NOS6 & Bacillus tequilensis & Bacilli & JQ905083 & 99.3 \\
\hline 25 & NOS14 & Bacillus vallismortis & Bacilli & JQ905084 & 100 \\
\hline 26 & NOS48 & Bacillus soli & Bacilli & JQ905085 & 97.9 \\
\hline 27 & ASW1* & Pseudoalteromonas mariniglutinosa & $\gamma$-Proteobacteria & JQ905086 & 99.8 \\
\hline 28 & ASW2A & Idiomarina baltica & $\gamma$-Proteobacteria & JQ905087 & 99.5 \\
\hline 29 & ASW2C & Staphylococcus succinus & Bacilli & JQ905088 & 99.9 \\
\hline 30 & ASW4A & Pseudoalteromonas sp. & $\gamma$-Proteobacteria & JQ905089 & 96.8 \\
\hline 31 & ASW4C* & Rheinheimera aquimaris & $\gamma$-Proteobacteria & JQ905090 & 98.7 \\
\hline 32 & ASW16 & Pseudoalteromonas lipolytica & $\gamma$-Proteobacteria & JQ905091 & 98.3 \\
\hline 33 & ASS1 & Bacillus tequilensis & Bacilli & JQ905092 & 98.8 \\
\hline 34 & ASS2A & Uncultured Marinobacter & $\gamma$-Proteobacteria & JQ905093 & 94.7 \\
\hline 35 & ASS2B $^{\star}$ & Marinobacter guineae & $\gamma$-Proteobacteria & JQ905094 & 97.9 \\
\hline 36 & ASS3B $^{\star}$ & Halomonas axialensis & $\gamma$-Proteobacteria & JQ905095 & 98.7 \\
\hline 37 & ASS4B & Bacillus subtilis & Bacilli & JQ905096 & 99.8 \\
\hline 38 & 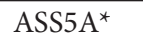 & Pseudoalteromonas sp. & $\gamma$-Proteobacteria & JQ905097 & 96.8 \\
\hline 39 & ASS5B* & Pseudoalteromonas lipolytica & $\gamma$-Proteobacteria & JQ905098 & 98.1 \\
\hline
\end{tabular}

* Siderophore producing bacteria in this study. Serial numbers 1-26 are Indian Ocean bacteria; 27-39 are Arabian Sea bacteria.

associated with hydrothermal activity or rendered ocean crust that are difficult to study. Gallionella ferruginea, Leptothrix spp, Sideroxydans spp., Mariprofundus ferrooxydans and Thiobacillus ferrooxidans were well documented iron oxidizing bacteria isolated from various aquatic environments (Emerson et al., 2010). On the other hand Pseudoalteromonas, Pseudomonas,
Vibrio, Halomonas, Marinobacter, Shewanella and Idiomarina are some of the other organisms which could do better iron oxidation (Sudek et al., 2009). Present investigation conducted from the AS and EIO were also shown that the heterotrophic organisms (Table I) belongs to $\gamma$ - and $\alpha$-Proteobacteria were able to perform better iron oxidation than the traditional ones 


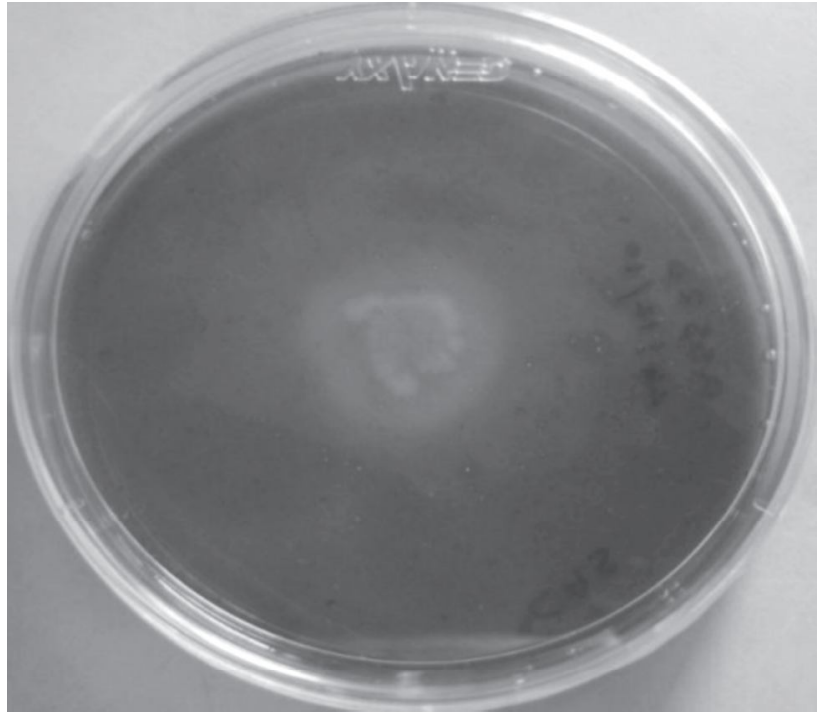

Fig. 3. CAS agar plate showing siderophore production by the strain ASS5B.

(iron bacteria). Similar results were also obtained through $\gamma$-Proteobacteria Marinobacter and Halomonas by Edwards et al (2003).

Among the three main classes from across the EIO and AS, samples Bacillus spp. being one of the key organisms in marine heterotrophic bacterial community. This is because of their diverse nature and widespread adaptability to the environmental conditions (Parvathi et al., 2009). Most of the Bacillus spp. obtained here were from the sediment samples at deeper depth (approx $4700 \mathrm{~m}$ ) and that could be known for its adaptation and survival through spore forming in geologic environments (Vreeland et al., 2000). We have noticed an interesting thing that the bacteria belong to a-Proteobacteria obtained only from the EIO water samples (Table I and Fig. 2a) and Pseudoalteromonas sp. could retrieve only from AS samples. Halomonas,

Table II

Siderophore production estimation in TYES broth and in CAS plates.

\begin{tabular}{|l|c|c|c|c|}
\hline \multirow{2}{*}{$\begin{array}{c}\text { Test } \\
\text { isolates }\end{array}$} & \multirow{2}{*}{$\begin{array}{c}\text { Isolation } \\
\text { source }\end{array}$} & $\begin{array}{c}\text { Siderophore } \\
\text { production } \\
\text { zone in CAS } \\
\text { plates (cm) }\end{array}$ & \multicolumn{2}{|c|}{$\begin{array}{c}\text { \% of siderophore } \\
\text { production }\end{array}$} \\
\cline { 4 - 5 } & & 3 & 85.3 & 81.3 \\
\hline ASW1 & AS & 1 & 44.4 & 26.02 \\
\hline ASW4C & AS & 2 & 87.9 & 84.07 \\
\hline ASS2B & AS & 1 & 87.5 & 77.9 \\
\hline ASS3B & AS & 3 & 81.3 & 71.1 \\
\hline ASS5A & AS & 3 & 78.3 & 54.16 \\
\hline ASS5B & AS & 1 & 78.6 & 71.5 \\
\hline OW10 & EIO & 2 & 59.1 & 35.8 \\
\hline OW16 & EIO & 2 & 73.3 & 52.7 \\
\hline OS38A & EIO & & & \\
\hline
\end{tabular}

Rheinheimera, Staphylococcus were some of the other genera obtained from AS samples (Fig. 2b). Marinobacter spp were common in both the study area.

Among the 39 strains tested for siderophore production, 9 of them produced yellow/orange colour around the colony (Fig. 3). Maximum diameter of the zone was $3 \mathrm{~cm}$ produced by Pseudoalteromonas sp. (ASW1, ASS5A and ASS5B) (Table II). Interestingly all the three Pseudoalteromonas sp. were affiliated to different $16 \mathrm{~S}$ rRNA gene sequences which is evidenced in phylogenetic tree. Among the 9 strains produced siderophores 8 of them belong to $\gamma$-Proteobacteria and the remaining one to $a$-Proteobacteria. Bacteria belong to $y$-Proteobacteria like Marinobacter and Halomonas are known for its production of self-assembling amphiphilic siderophores (Martinez et al., 2000). Our studies were also in supportive of the above by saying Marinobacter, Halomonas, Pseudoalteromonas, Rheinheimera and Pseudomonas could produce siderophores in a better way. Though the previous reports say the transport of iron through siderophores by Bacillus spp. (Dertz et al., 2003; Zawadzka et al., 2009) we did not see siderophore production from Bacillus spp. The reasons are not known.

Siderophore production tested among the 9 strains using various techniques expressed its maximum production from the ASS2b strain with 87.9\%. The lowest production was noticed in ASW4c at the rate of $44.4 \%$ (Table II). While comparing the siderophore production rates, the AS strain has given much higher when compared to EIO. Quantitative estimation of siderophores have shown that $6^{\text {th }}$ day old culture produces maximum amount of siderophores as compared to $12^{\text {th }}$ day old culture. Further the samples which produced siderophores were scanned to get a rough idea of the compounds present over there. All the 9 strains scanned for siderophore production indicate 2 peaks, one at 306 and the other at $246 \mathrm{~nm}$ (Fig. 4) (UV-scan data are not presented beyond 400nm in Figure 4 since there is no peak after). These peaks indicate the compound Azurechelin (Sokol et al., 1992). They say that $88 \%$ of siderophore production by Pseudomonas cepacia had absorbance maxima at 240 and $310 \mathrm{~nm}$. Our reports also indicate the peak in a similar fashion, it could be interpreted that the EIO and AS samples may produced the same compound.

Most of the microbial siderophores are either hydroxamate or catechol or carboxylate types (Miethke and Marahiel, 2007). All the bacteria from the present study were showing the absorption maxima between 190 and 280 (Spectrophotometric Scan) which indicate the presence of carboxylate type. Interestingly, bacterial siderophore production studies conducted by Sullivan et al. (2012) also revealed that in general $90 \%$ of the bacterial isolates were able to produce carboxylates type siderophores. 

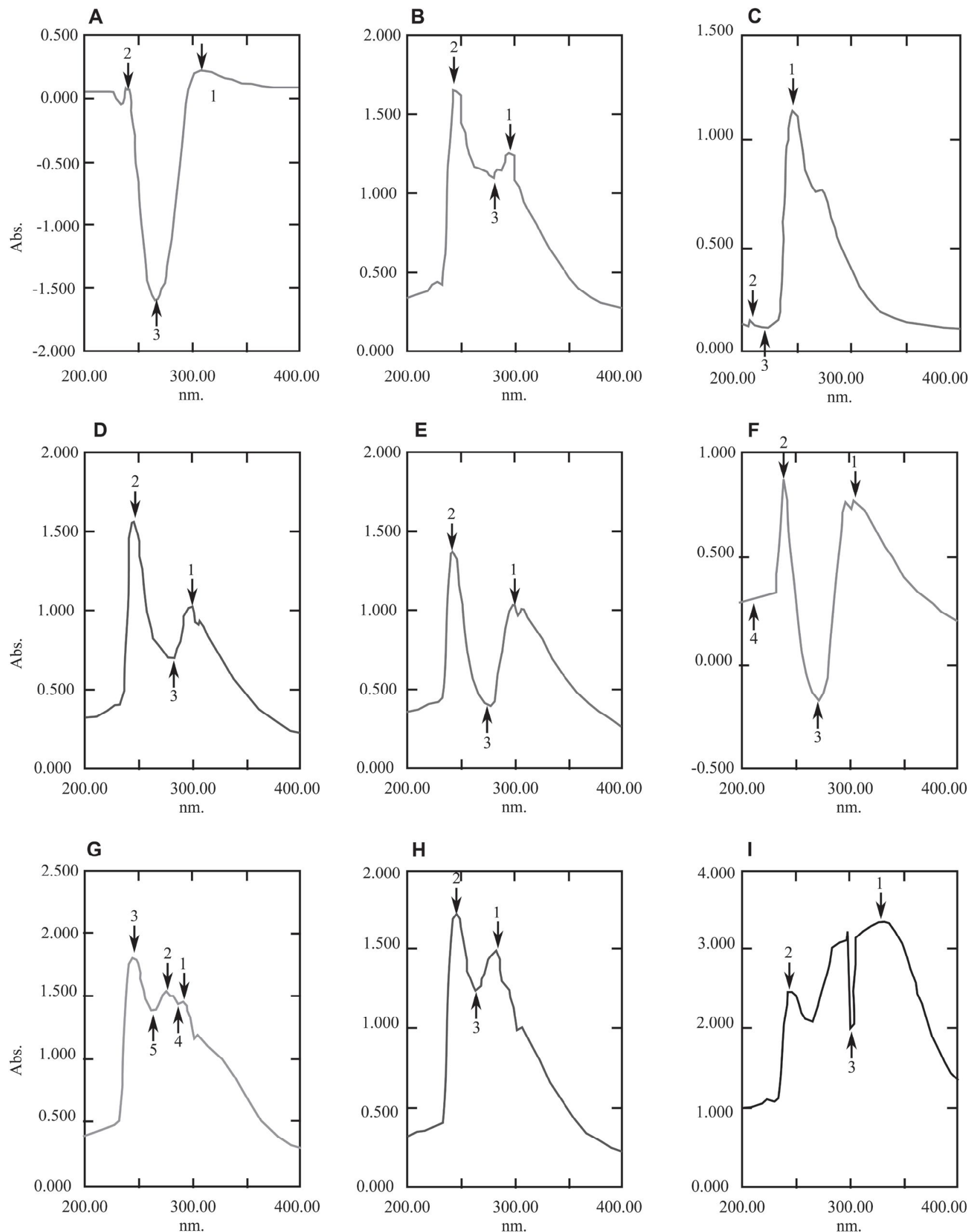

Fig. 4. Scan report for various siderophore producing bacterial strains tested under UV-Visible spectrophotometer (A: ASW1, B: ASW4C, C: ASS2B, D: ASS3B, E: ASS5A, F: ASS5B, G: OW10, H: OW16, I: OS38A).

Importance of heterotrophic bacteria in the cycling of carbon and nutrients, including iron is not fully understood (Tortell et al., 1996). This is especially so from oligotrophic waters (Fukuda etal., 1998). In general, the dissolved Fe concentration in the surface mixed layer was lower due to biological removal and 
excess concentration of Fe-binding organic ligands (Nakabayashi et al., 2001 and 2002). Studies by Price et al. (1994) and Cochlan (2001) in the eastern Equatorial Pacific Ocean, and Pakulski et al. (1996) in Gerlache Strait explained that, even small quantities of iron could increase the heterotrophic bacterial abundance.

Current study on the diversity of culturable iron bacteria from the EIO and AS samples showed that the bacteria retrieved from the selective medium did not indicate any typical iron bacteria like Thiobacillus. On the other hand the bacterial groups like Pseudoalteromonas, Halomonas, Idiomarina. Erythrobacter, and Nitratireductor were retrieved during this study. These kind of heterotrophic organisms were well reported earlier for iron oxidation. Distinct variation on the diversity of iron bacteria were noticed in the analyzed sites indicating Erythrobacter, Roseovarius, Sagittula and Nitratireductor from the oligotrophic waters of EIO and Pseudoalteromonas, Halomonas, Rheinheimera, Staphylococcus and Idiomarina in nutrient rich waters of AS. Very few isolates like Marinobacter and Bacillus were common in both the seas.

Iron can be used in two ways by the microorganisms, one as an electron acceptor which oxidize iron directly and the others which produce siderophores to solubilize the iron for its nutritional requirements. Since the isolates Marinobacter hydrocarbonoclasticus, Nitratireductor kimnyeongensis and Pseudomonas stutzeri (EIO) and Pseudoalteromonas spp, Marinobacter guinea, Rheinheimera aquimaris and Halomonas axialensis (AS) exhibit to produce siderophores, we assume that these organisms meet their iron requirement through siderophore production. Though Bacillus spp reported for siderophore production earlier, our investigations did not come across Bacillus spp. for siderophore production in the study area and the reasons are yet to be studied. In general from the current study it may be interpreted that the bacterial species from the oligotrophic waters like EIO try to obtain their iron requirement by oxidation and the bacteria of AS through siderophore production. Further most of the iron solubilising marine bacteria expected to synthesize similar type of compounds in their siderophore. This work reported to bring few new species and genus in bacterial diversity on iron oxidation.

\section{Acknowledgements}

We acknowledge Dr. V.K Banakar for partial financial support from the project "Studies on Cobalt Crusts Exploration". Thanks to the captain and crew members of RV Boris Petrov (ABP\#37) and CRV Sagar Sukti (SASU\#185) for their support. We are thankful to the Director, N.I.O. and DU leader Dr. N. Ramaiah for his comments and suggestion to improve upon the manuscript. We extend our thanks to Binnie Williams and Deepika Sisodya for their technical support. R.R thanks the Council of Scientific and Industrial Research (CSIR) for the award of SRF. (This is CSIR-NIO contribution number 5514)

\section{Literature}

Andrews S.C., A.K. Robinson and F Rodriguez-Quinones. 2003. Bacterial iron homeostasis. FEMS Microbiol. Rev. 27: 215-237.

Arnow L.E. 1937. Colorimetric determination of the components of 3,4-dihydroxyphnyl-alanine tyrosine mixtures. J. Biol. Chem.118: 531-537

Ashelford K.E., N.A. Chuzhanova, J.C. Fry, A.J. Jones and A.J. Weightman. 2005. At least 1 in 20 16S rRNA sequence records currently held in public repositories is estimated to contain substantial anomalies. Appl. Environ. Microbiol. 71: 7724-7736.

Cameron F.J., M.V. Jones and C. Edwards. 1984. Effects of salinity on bacterial iron oxidation. Curr. Microbiol. 10(6): 353-356.

Cochlan W.P. 2001. The heterotrophic bacterial response during a mesoscale iron enrichment experiment (IronEx II) in the eastern equatorial Pacific Ocean. Limnol. Oceanogr. 46(2): 428-435.

Cornell R.M. and U. Schwertmann. 1996. The iron oxides: Structure, properties, reactions, occurrence and uses. 2nd ed. John Wiley and Sons, Weinheim, Germany.

Dertz E.A., A. Stintzi and K.N. Raymond. 2006. Siderophoremediated Iron Transport in B. subtilis and C. glutamicum. J. Biol. Inorg, Chem. 11: 1087-1097.

D’Onofrio A., J.M. Crawford, E.J. Stewart, K. Witt, E. Gavrish, S. Epstein, J. Clardy and K. Lewis. 2010. Siderophores from neighboring organisms promote the growth of uncultured bacteria. Chem. Biol. 17: 254-264.

Edwards K.J., W. Bach, T.M. McCollom and D.R. Rogers. 2004. Neutrophilic Iron-Oxidizing Bacteria in the Ocean: Their Ilabitats, Diversity, and Roles in Mineral Deposition, Rock Alteration, and Biomass Production in the Deep-Sea. Geomicrobiol. J. 21: 393-404. Edwards K.J., D.R. Rogers, C.O. Wirsen and T.M. McCollom. 2003. Isolation and characterization of novel psychrophilic, neutrophilic, Fe-oxidizing chemolitho-autotrophic $\alpha$ - and $y$-Proteobacteria from the deep sea. Appl. Environ. Microbiol. 69: 2906-2913.

Emerson D., E.J. Fleming and J.M. McBeth. 2010. Iron-Oxidizing Bacteria: An Environmental and Genomic Perspective. Annu. Rev. Microbiol. 64: 561-583.

Fukuda R., H. Ogawa, T. Nagata and I. Koike. 1998. Direct determination of carbon and nitrogen contents of natural bacterial assemblages in marine environments. Appl. Environ. Microbiol. 64: 3352-3358.

Lane D.J. 1991. 16S/23S rRNA sequencing, pp. 115-175. In: Stackebrandt $\mathrm{E}$ and M. Goodfellow (Eds). Nucleic acid techniques in bacterial systematic. John Wiley and Sons, New York.

Martinez J.S., G.P. Zhang, P.D. Holt, H.T. Jung, C.J. Carrano, M.G. Haygood and A. Butler. 2000. Self-assembling amphiphilic siderophores from marine bacteria. Science 287: 1245-1247.

Miethke M. and M.A. Marahiel. 2007. Siderophore-based iron acquisition and pathogen control. Microbiol. Mol. Biol. Rev. 71: 413-451.

Neilands J.B. 1981. Microbial iron compounds. Annu. Rev. Biochem. 50: 715-731.

Nakabayashi S., K. Kuma, K. Sasaoka, S. Saitoh, M. Mochizuki, N. Shiga and M. Kusakabe. 2002. Variation in iron(III) solubility and iron concentration in the northwestern North Pacific Ocean. Limnol. Oceanogr. 47: 885-892.

Nakabayashi S., M. Kusakabe, K. Kuma and I. Kudo. 2001. Vertical distributions of iron(III) hydroxide solubility and dissolved iron in the north-western North Pacific Ocean. Geophys. Res. Lett. 28: 4611-4614.

Okujo N., M. Saito, S. Yamamoto, T. Yoshida, S. Miyoshi and S. Shinoda. 1994. Structure of vulnibactin, a new polyamine-containing siderophore from Vibrio vulnificus. Biometals 7: 109-116.

Pakulski J.D., R.B. Coffin, C.A. Kelley, S. Holder, R. Downer, A.A.S. Peter, M.M. Lyons and W.H. Jeffrey. 1996. Iron stimulation of Antarctica bacteria. Nature 383: 133-134. 
Parvathi A., K. Krishna, J. Jose, N. Joseph and S. Nair. 2009. Biochemical and molecular characterization of Bacillus pumilus isolated from coastal environment in Cochin, India. Braz. J. Microbiol. 40: 269-275.

Payne S.M. 1994. Detection, isolation and characterisation of siderophores. Method. Enzymol. 235: 329-344.

Price N.M., B.A. Ahner and F.M.M. Morel. 1994. The equatorial Pacific Ocean: Grazer controlled phytoplankton populations in an iron-limited ecosystem. Limnol. Oceanogr. 39: 520-534.

Reid R.T. and A. Butler. 1991. Investigation of mechanism of iron acquisition by marine bacterium Alteromonas luteoviolaceus: Characterization of siderophore production. Limnol. Oceanogr. 36: 1783-1792.

Schalk I.J., M. Hannauer and A. Braud. 2011. New roles for bacterial siderophores in metal transport and tolerance. Environ. Microbiol. 13: 2844-2854.

Schwyn B. and J.B. Neilands. 1987. Universal chemical assay for the detection and determination of siderophores. Anal. Biochem. 160: 47-56.

Shenker M., I. Oliver, M. Helmann, Y. Hadar and Y. Chen. 1992. Utilization by tomatoes of iron mediated by a siderophore produced by Rhizopus arrhizus. J. Plant. Nutr. 15: 2173-2181.

Snow G.A. 1954. Mycobactin, a growth factor for Mycobacterium johnei. Part II. Degradation and identification of fragments. J. Chem. Soc. 2588-2596

Sogaard E.G., R. Aruna, J. Abraham-Peskir and C.B. Koch. 2001. Conditions for biological precipitation of iron by Gallionella ferruginea in a slightly polluted ground water. Appl. Geochem. 16: 1129-1137.

Sokol P.A., C.J. Lewis and J.J. Dennis. 1992. Isolation of a novel siderophore from Pseudomonas cepacia. J. Med. Microbiol. 36: 184-189. Sudek L.A., A.S. Templeton, B.M. Tebo and H. Staudige. 2009. Microbial Ecology of Fe (hydr) oxide Mats and Basaltic Rock from Vailulu’u Seamount, American Samoa. Geomicrobiol. J. 26: 581-596.
Sullivan T.S., S. Ramkissoon, V.H. Garrison, A. Ramsubhag and J.E. Thies. 2012. Siderophore production of African dust microorganisms over Trinidad and Tobago. Aerobiologia 28: 391-401. Tamura K., J. Dudley, M. Nei and S. Kumar. 2007. MEGA4: Molecular Evolutionary Genetics Analysis (MEGA) software version 4.0. Mol. Biol. Evol. 24: 1596-1599.

Tamura K., M. Nei and S. Kumar. 2004. Prospects for inferring very large phylogenies by using the neighbor-joining method. Proceedings of the National Academy of Sciences, USA 101: 11030-11035.

Thompson J.D., T.J. Gibson, F. Plewniak, F. Jeanmougin and D.G. Higgins. 1997. The ClustalX windows interface: flexible strategies for multiple sequence alignment aided by quality analysis tools. Nucleic. Acids. Res. 24: 4876-4882.

Tortell P.D., M.T. Maldonado and N.M. Price. 1996. The role of heterotrophic bacteria in iron-limited ocean ecosystems. Nature 383: 330-332.

Trick C.G. 1989. Hydroxamate-siderophore production and utilization by marine eubacteria. Curr. Microbiol. 18: 375-378.

Turner D.R., and K.A. Hunter. 2001. The biogeochemistry of iron in seawater. IUPAC series on analytical and physical chemistry of environmental systems. Vol. 7. John Wiley and Sons, New York.

Vreeland R.H., W.D. Rosenzweig and D.W. Powers. 2000. Isolation of a 250 million-year-old halotolerant bacterium from a primary salt crystal. Nature 407: 897-900.

Wang J., G. Muyzer, P.L. Bodelier and H.J. Laanbroek. 2009. Diversity of iron oxidizers in wetland soils revealed by novel 16S rRNA primers targeting Gallionella related bacteria. ISME. J. 3: 715-725. Wu J. and G.W. Luther. 1994. Size-fractionated iron concentrations in the water column of the western North Atlantic Ocean. Limnol. Oceanogr. 39(5): 1119-1129.

Zawadzka A.M., R.J. Abergel, R. Nichiporuk, U.N. Andersen and K.N. Raymond. 2009. Siderophore-Mediated Iron Acquisition Systems in Bacillus cereus: Identification of Receptors for Anthrax Virulence-Associated Petrobactin. Biochem. J. 48: 3645-3657. 